Journal of The Faculty of Science and Technology (JFST)

http://journal.oiu.edu.sd/index.php/JFST

https://doi.org/10.52981/jfst.vi7.963

ISSN: 1858 - 6007

مجلة العلوم و التقانة - جامعة أم درمان الإسلامية - وزارة التعليم العالي و البحث العلمي ـ السودان

Research article

JFST Issue No. 7 (2020) 110 - 116

\title{
Antioxidant activity of some Sudanese medicinal plant methanolic extracts
}

\author{
Manal A Ibrahim, Safa G Ali, Mahasin M Hussien \\ Department of Botany, Faculty of Science and Technology, Omdurman Islamic \\ University, Sudan. \\ $\underline{\text { manalabdalla071@gmail.com, manalabdalla@oiu.edu.sd }}$
}

\begin{abstract}
Traditional medicines play a very important role in the health care system in Sudan, Cadaba glandulosa, Aristolochia bracteolata , Boscia senegalensis and Nymphaea lotus are used in folkloric medicine to remedy some diseases. The methanolic extracts were used to evaluate antioxidant activity to the plants which were mentioned above. B senglensis was shown high activity equal to $87+1$, while $N$. lotus was represented $82+2$. Also $A$. bracteolate and C. glandulosa exhibited moderate values $(54+0.03$ and $41+0.04$ respectively).
\end{abstract}

\section{Key words}

Cadaba glandulosa , Aristolochia bracteolata , Boscia senegalensis , Nymphaea lotus, DPPH and Antioxidant Activity.

\section{Introduction}

The many number of medicinal plants are used in the cellular and metabolic disease treatment such as diabetes, obesity and cancer etc. There are some speculations that the generation of free radicals inside the body in some physiological conditions is resulted in the cellular changes and development of cancer etc. and this could be neutralized by the antioxidants from different medicinal plants. Several studies have shown that plant derived antioxidant nutraceuticals scavenge free radicals and modulate oxidative stress-related degenerative effects( Ames et. al, 1993), (Joseph et. al, 1999) Free radicals have been implicated in many diseases such as cancer, atherosclerosis, diabetes, neurodegenerative disorders and aging (Halliwell et. al, 1999), (Yu, 1994). Previous research reports suggest 
that higher intake of antioxidant rich food is associated with decreased risk of degenerative diseases particularly cardiovascular diseases and cancer (Thatte et. al, 2000).

The free radical neutralizing property of several plants was reported by previous studies. The extracts from number of medicinal plants which are known to have some biologically active principles are used in ayurvedic preparations and these extracts are prepared in bulk for commercial purpose. The importance of the antioxidant constituents of plant materials in the maintenance of health and protection from coronary heart disease and cancer is also raising interest among scientists, food manufacturers, and consumers as the trend of the future is moving toward functional food with specific health effects (Lo“-liger, 1991).

Nymphaea Lotus (family Nymphaeaceae) plant has a common name Soutab, Umm Ban geiga. It is aquatic pubescent herbs with submerged prostrate rhizomes, widespread throughout central and southern Sudan. (El Ghazali et al.,1997). It was used in traditional medicine system as an aphrodisiac, anodyne, astringent, cardiotonic, sedative, demulcent, analgesic and as anti-inflammatory agent (Madhusudhanan et al, 2011). Many biological activities, including anticancer and antiviral has been attributed to Gallic and ellagic acid which are widely present in $N$. lotus (Thippeswamy et al.,2011).

Boscia senegalensis which has a common name Elcrasan - Elmekheat belong to family Capparacea. It is shrubs or small trees, the plant occurs across the hunger area It is usually eaten as a food with oil and salt as a famine food. Alternatively, seeds ground flour were consumed in the form of kisra, flat thin bread popular in Sudan or Asida, a local form of porridge. (NRC, 2008) The leaves were used to protect stored food against parasites (Hans, 2000). According to the African folk medicine, an infusion of leaves were used to remove intestinal parasites from camels. Infusion of the leaves is used as an eye-wash, pruritus of the eye due to syphilis and to relief intestinal pain. (Orwa et al., 2009).

Also Cadaba glandulosa (common name Elsrah). (Family Capparaceae ). It is a Shrub $0.3-1.5 \mathrm{~m}$ tall. The leaves are used for the treatment of hemorrhoids and urinary tract infections (Al-Fatimi et al., 2007) leaves, seeds and roots of the plant are widely used as an anthelmintic, antiscorbutic, antiseptic, cardiac stimulant, carminative, febrifuge sudorific, anticonvulsant, antidi- arrhoeal, and are also used to treat skin diseases. (Mohtasheem et al., 2011). 
Aristolochia bracteolate, Family Aristolochiaceae, which is traditionally used to cure for scorpion and snake bites, pain, tumor, malaria and fever (El Ghazali et al., 1994). In African ethnomedicine, it is widely used as anti-inflammatory and anticancer (Abubakar et al., 2007). The plant is known as "worm killer" due to supposed anthelmintic activity and trypanocidal effect. Furthermore, the A. bracteolata possesses potent anti-allergic, antibacterial and antifungal activities (Abdelgadir et al., 2011).

The methanolic extract of the plant's root showed the low toxicity on human cells (Eltahir et al., 1999). The reputed trypanocidal activity of A. bracteolate was also assessed. Different plant extracts were administered to Trypanosoma evans infected rats, where the chloroform extract gave an outstanding parasitic blood clearance (100\%) and the methanol extract showed a limited trypanocidal effect. (Abdelrahman, 2011). Several root's extracts were tested against cutaneous melanoma cell line. The petroleum ether extract notably reduced cell survival. (Thirumal et al., 2012). Aristolochic acids are known to be toxic and a rodent carcinogen, in addition to their carcinogenicity, aristolochic acids are also highly nephrotoxic agents. (Jou et al., 2004).

The importance of the antioxidant constituents of plant materials is the maintenance of health and protection from coronary heart disease and cancer. Therefor this study aimed to evaluate the antioxidant activity of methanolic plant extracts as a new potential source of natural anti - tumor agent.

\section{Materials and methods}

\section{Plant materials}

The Plants under investigations ( Cadaba glandulosa, Aristolochia bracteolata , Boscia senegalensis ), Leaves and Nymphaea lotus whole plant were Collected in April 2017 from Gabrat ALsheakh and Kadogly in South Kordofan and from Khartoum region. The plants were taxonomically identified by Dr. Manal Abdalla, Department of Botany, Faculty of Science and Technology, Omdurman Islamic University, and Mr. Yahya, Medicinal and Aromatic Plants Institute, National Center for Research. 


\section{Preparation of Extracts}

Plant parts (leaves and Nymphaea lotus whole plant) were dried at room temperature in order to avoid any changes that may alter their chemical composition. Then, they were ground to a coarse powder before they were handled according to Harborne (1998). 100gm of plant materials were soaked overnight with $350 \mathrm{ml} 98 \%$ methanol in $500 \mathrm{ml}$ conical flask. Then the extracts were filtered, evaporated to dryness under reduced pressure in a rotatory evaporator and weighted.

\section{DPPH radical scavenging assay:}

The DPPH radical scavenging was determined according to Villaño et al., 2007 the method of with some modifications. In 96- wells plate, the test samples allowed to react with 2.2Di (4-tert- octylphenyl) - 1- paicryl-hydrazylstable free radical (DPPH) for half an hour at 37C. . The concatenation of DPPH was kept as (300uM). The test samples were dissolved in DMSO while DPPH was prepared in ethanol. After incubation, the absorbance was measured at $517 \mathrm{~nm}$ using multilane reader spectrophotometer. Percentage radical scavenging activity by samples was determined in comparison with a DMSO trained control group. All tests and analysis were run in triplicate

\section{Results and Discussion}

Antioxidant mechanisms include radical-scavenging (both hydrogen-donating capability and free radical quenching activity, inhibition of lipid peroxidation, metal ion chelation, or combination of these properties (Sarmadi and Ismail, 2010) Antioxidant activities might protect biological systems against damage related to oxidative stress in human disease conditions. These antioxidant peptides might also be employed in preventing oxidation reactions (such as lipid peroxidation) that leads to deterioration of foods and foodstuffs (Hogan et. al, 2009).

The antioxidant activity which was made a according to method described by shamed et. al, (1992) revealed positive results. Table (1) showed high percentage as represent by B. senegalensis $(88+0.01 \%)$ compared with the control $(93+0.01 \%)$. Vouga et. al, (2014) reported that $B$. senegalensis represented high antioxidant activity when they used methanolic extract. Also N. lotus showed high value too $(82+0.2 \%)$. Anthony 
et al, (2014) stated that the acetone extract of $N$. lotus displayed better DPPH and no radical scavenging activity than the aqueous extract and this reflected in its low $\mathrm{IC}_{50}(0.016 \mathrm{mg} \mathrm{mL}-1)$ which compares favorably with the standards. Also the study revealed that $N$. lotus is very rich in phytochemicals and is a good source of natural antioxidants. This confirms and validates its use for the treatment of several diseases in human. A. bracteolota and .C glandulosa exhibited moderate results (54+0.03and $41+0.04 \%$ respectively). A previous chemical study of the ethanolic extract of $C$. rotundifolia root from the same species yielded a quaternary alkaloid (3hydroxystachydrine) and high antioxidant activity ( Al-Hamoud et.al, 2012) . However, no report on free radical scavenging of the leaves of C. glandulosa has been issued.

Table 1:Antioxidant activity of plant extracts

\begin{tabular}{ll}
\hline \multicolumn{1}{c}{ Plant species } & (DPPH \%) \\
\hline Nymphaea lotus & $82+0.02$ \\
Boscia senegalensis & $88+0.01$ \\
Cadaba glandulosa & $41+0.04$ \\
Aristolochia bracteolota & $54+0.03$ \\
Propyl galate & $93+0.01$ \\
\hline
\end{tabular}

\section{Conclusion}

We concluded that $B$. senegalensis and $N$. lotus are very rich in antioxidant compounds and they are a good source of natural antioxidants.

\section{References}

Abdelgadir, A.A. Ahmed, E.M. and Eltohami, M.S. (2011). Isolation Characterization and Quantity Determination of Aristolochic Acids, Toxic Compounds in Aristolochia bracteolata L. Environ Health Insights, 5: 1-8.

Abubakar, M.S, Musab, A.M. Ahmeda, A. and Hussaini, I.M. (2007). The Perception and Practice of Traditional Medicine in the Treatment of Cancers and Inflammations by 
the Hausa and Fulani Tribes of Northern Nigeria. Journal of Ethno pharmacology, 111: $625-629$.

Al-Fatimi, M. M. Wurster, G. Schroder, and U. Lindequist. (2009). Antioxidant, antimicrobial and cytotoxic activities of selected medicinal plants from Yemen. Journal of Ethno - pharmacology, 111: 657-666.

Al-Hamoud G A. Orfali R S, Yamano Y, Alothyqi N Alzahrani A M, Matsunami K (2012). Four New Flavonoids Isolated from the Aerial Parts of Cadaba rotundifolia Forssk. (Qadab) Journals of Molecules 24 : 11,112-119.

Ames B N, Shigenaga M K , Hagen T M (1993). Academy of Sciences of the United States of America, 90, 7915-7922.

Anthony Jide Afolayan, Olubunmi Josephine Sharaibi and Mutiu Idowu Kazeem (2014). Phytochemical Analysis and in vitro Antioxidant Activity of Nymphaea lotus L.. International Journal of Pharmacology, 9: 297-300.

NRC: National Research Concil. (2008). Aizen-Mukheit Lost crop of Africa Fruit.part National Academies Press.Washington DC., III. 220_230.

EL Ghazali, G.E.B. Eltohami M.S and ELgami, A.A.B. Abdella. W.S. and Mahmoud, M,G,(1997). Medicinal plants of the Sudan part Iv, MBd. Plants of Nor Thern Kordofan, Khartoum Omdurman Islamic uni. print and publishing House.

El Ghazali, GEB, El Tohami. M.S. and El Egami, A. AB. (1994). Medicinal Plants of the Sudan Part III in Medicinal Plants of the White Nile Provinces. National council for Research. Khartoum.

Halliwell B and Gutteridge J M, Oxford: Oxford University Press, 1999.

Hans, D.N. (2000). African Traditional medicine. A dictionary of Plants Use and Applications, Ed Med. pp. 371.

Harborne, J.B., (1998). Phytochemical Methods: A Guide to Modern Techniques of Plant Analysis. 3rd Edn., Chapman and Hall, London, ISBN-13: 9780412572708, Pages: 302.

Hogan S Zhang L Wang H Zho K (2009). Food Chem., 117, 438-443.

Joseph J A, Shukitt-Hale B, Denisova N A, Bielinski D, Martin A, McEwen J J, Neurosci P C (1999) 19(18), 8114-8121. 
Lo“liger, J. (1991).The use of antioxidants in food. In Free Radicals and Food Additives; Aruoma, O. I., Halliwell, B., Eds.; Taylor and Francis: London. 129-150.

Madhusudhanan, N. Lakshmi, T. Kumar, S.G. Venu, G. (2011). In vitro antioxidant and free radical scavenging activity of aqueous and ethanolic flower extract of Nymphaea Alba Int J Drug Dev Res, 3(3): 252-258.

Mohtasheem ul Hasan, M. Salman, A. Munnawar, S. Iqbal, A. (2011). Analgesic and Anti - emetic activity of Cleome viscosa L. Pak J Bot .1., 43(1): 119-2.

Orwa, C. Mutua, A. Kindt, R. Jamnadass, R. Anthony, S. (2009). Agroforestree Database: a tree reference and selection guide version 4.0.

Sarmadi BH Ismail A ( 2010 ). Antioxidant activity of some medicinal plants. Peptides, 31, 1949-1956.

Thatte U, Bagadey S and Dahanukar S (2000). Mole Cellular Biochem., , 46, 199-214

Thippeswamy, B.S. Brijesh, M. Veerapur, V.P. Gourav, G. (2011). Anxiolytic activity of Nymphea alba Linn. in mi ce as experimental models of anxiety. Indian J Pharmacol,43: 50-55. Villaño D, Fernández-Pachón MS, Moyá ML, Troncoso AM,GarcíaParrilla MC (2007). Radical scavenging ability of polyphenolic compounds towards DPPH free radical. Talanta 71(1):230-235.

Vouga R R, Foyet H S, Ziebe R, Rebecca B. G (2014). Antioxidant activity and phytochemical constituent of two plants used to manage foot and mouth disease in the Far North Region of Cameroon. Journal of Intercultural Ethnopharmacology,12:3,189-199. 